\title{
Gastronomic Tourism Attractions in the Kapau Village, Agam Regency, West Sumatra
}

\author{
Putri Andan Sari ${ }^{1}$, Dewi Turgarini ${ }^{1}$, Indriyani Handyastuti ${ }^{2}$ \\ ${ }^{1}$ Indonesia University of Education, Jl. Dr. Setiabudhi No. 229, Bandung 40154, Indonesia \\ ${ }^{2}$ Bandung College of Tourism, Jl. Dr. Setiabudi No.186, Hegarmanah, Kec. Cidadap, Kota \\ Bandung, Jawa Barat 40141
}

*Corresponding Author. E-mail: putriandans@yahoo.com (Putri Andan Sari)

\begin{tabular}{|l} 
ABSTRACT \\
This research's aim is to find out the grand of gastronomy in Kapau, the components of \\
gastronomy in Kapau, people 's contributions and government acts to preserve traditional \\
gastronomy in Kapau, Agam, West Sumatra. Kapau, is a small region in West Sumatra that is \\
known by fine traditional foods that have a unique taste on every food they are made. Therefore, \\
Kapau is also known as a village that creates many expert chefs. To reach the aims written above, \\
this research uses the mix method both qualitative and quantitative. Observation, questionnaire, \\
interview and some documentary studies used to get the data. The result of this research is shows \\
that Kapau Rice is a kind of traditional gastronomy that is very famous, not only among the \\
Kapau citizens, but it is also known by the larger society outside. Regarding gastronomic tourist \\
attractions in Kapau Village, Kapau rice has a good and unique taste and which cannot be found in \\
other food. Gastronomy conservation has been done by government, chefs, and local leaders of \\
the village by passing the cooking method from generation to generation. As a recommendation \\
gastronomic travel pattern has been made in order to conserve traditional gastronomic in Kapau \\
Village. Kapau rice consist of diverse Kapau traditional food such as Rendang, Gulai and \\
Dendeng. \\
Keywords: Kapau Rice; Gastronomy; Tourism. \\
First Received: April 2019 \\
Final Proof Received: Juni 2019 \\
Rublished: Juni $\mathbf{2 0 1 9}$
\end{tabular}




\section{Introduction}

Based on RI Law No.10 of 2009 concerning tourism, it means that tourism is: "A variety of activities supported by various facilities and services provided" With different objectives, this tourism activity is also one of the supporting aspects of development in all field in an area.

Tourism will never be separated by the existence of gastronomy because gastronomy can be used as a tourist attraction that is available at any time . (Nurwitasari, 2015) Gastronomy is a scientific study of the branch of science that studies the mixing of food ingredients from food ingredients and the cooking process as well as the phenomenon in consuming these foods.

One area in Indonesia that has various types of gastronomy is the Village of Kapau or Nagari Kapau located in Agam Regency, West Sumatra. According to Bondan Winarno, as reported by (detikFood, 2017) Nagari Kapau is a village that is famous for its shrewdness in cooking. With the shrewdness of its people, Kapau Village is known for its delicious cuisine. Not only that, the food processing in Kapau Village is very unique and has its own taste. All dishes in Kapau Village must be processed in a traditional manner and must use traditional and natural raw materials, in contrast to other dishes that are more modern because they already use spices and instant raw materials.

Agustino in the article (RRI, 2019) said that tourists who are visiting Agam Regency, especially Kapau Village, they are not only doing a recreational tour but also they also having culinary tours there. Therefore, the development of gastronomy as a tourism object must be carried out, because Kapau Village can support tourism development in Indonesia. That way, the tourism market segment in the Kapau Village will be more visible to find out how big the opportunity of Kapau Village to become a culinary tourist attraction in West
Sumatra. However, even though Kapau Village is famous for the expertise of its citizens in making delicious dishes, until now there has been no gastronomic icon chosen to become the identity of the area.

Based on the background that the researchers describe, the researcher wants to conduct research related to an inventory of superior traditional foods to be used as a gastronomic icon that can be a potential tourist attraction in the Kapau Village, Agam Regency.

\section{Literature Review}

\subsection{Culinary Traditions and Philosophy of West Sumatra}

\subsubsection{Eating Bajamba, A Togetherness}

Eating bajamba or eating barapak is a tradition of large meals together in the Minangkabau community. Bajamba meals are usually held at parties or baralek events, such as commemorating Islamic religious holidays, traditional ceremonies, and other important gatherings. Many values are instilled through eating bajamba, including togetherness without distinguishing social status, strengthening ties of friendship, instilling courtesy and mutual respect. (Kemenpar, 2017)

This tradition originated from Koto Gadang, Agam Regency, West Sumatra, since Islam entered Minangkabau around the 7th century. This tradition then spread to other nagari in Minangkabau.

Bajamba food is held with participants numbering in the tens to thousands of people. The participants were divided into groups of 3 to 7 people. Each group member will sit around this iron tray with a diameter of about $50 \mathrm{~cm}$, in which a plate of rice and various side dishes in the form of Minangkabau dishes will be arranged.

Some etiquette in this tradition include that someone can only take something after the older people, no sound when chewing or eat spicy food, because it will interfere with other people's appetite. There are also rules for feeding food, in which the hand cannot 
enter the mouth. The trick is to take a small mouthful of rice with the tips of the right hand, a little on the head. After adding a few side dishes - rice dishes are slightly tossed to the mouth with a rather close distance. (Kemenpar, 2017)

\subsubsection{Spicy Savory Minang Cuisine}

The Minangkabau region has been visited by other nations from the Arabian Peninsula, Persia and India even before the emergence of Islam. Anthropologically, cuisine spreads along with the spread of humans. This also presents the culinary wealth of Minangkabau. The main flavor of Minang cuisine is savory and spicy. The spices are: coconut milk, chili, onion and garlic, a series of four rhizome spices: galangal, lemongrass, ginger, turmeric, and aromatic leaves of fragrance makers namely turmeric, orange leaves, and occasionally bay leaves and bowl leaves. (Kemenpar, 2017)

Another key is the use of a lot of condiment. There is a traditional benchmark comparison of seasonings and raw materials which is 3: 8 . While the ratio of onions and garlic is 2: 1. Minang cuisine never uses sugar, either brown sugar or white sugar. (Kemenpar, 2017)

The raw materials in Minang cuisine are mainly animal raw materials, namely beef, chicken or duck, sea fish, freshwater fish, including chicken eggs. While more vegetables use long beans and cassava leaves, ferns, jackfruit, beans, and petai and jengkol. (Kemenpar, 2017)

\section{Materials and Methods}

The method used in this study is a qualitative method, namely in-depth study of something. According to Meleong (2007: 5) qualitative research is research that utilizes open interviews to examine and understand the attitudes, views, feelings and behavior of individuals or groups of people. The most important thing from an item or service is an event/phenomenon/social phenomenon that has the meaning behind the event that can be used as a valuable lesson for a development of theoretical concepts.

The approach method in this study will also use descriptive analysis. According to Wardiyanta (2006, p. 5) said that descriptive research is research that aims to make a description of a social/natural phenomenon systematically, factually and accurately. In addition, this research is often used to answer questions about various events that are happening in the community.

The object of this research is Kapau Rice, one of the traditional foods of Kapau Village, Agam Regency, West Sumatra with the subject being Kapau Village as a place for producers of Kapau Rice located in the area of Kapau Village, Agam Regency, West Sumatra, cooks, local government, customary stakeholders and society especially the younger generation. In this case the researcher wants to collect data on gastronomic preservation efforts by the government and the community as well as to find out what components are in the selected leading gastronomy of Agam Regency. This method is also expected to explore specific and general data on the leading gastronomy of Agam Regency.

The participants in this study were the people who were divided into elements related to the gastronomy of Agam Regency such as the people who consumed various kinds of gastronomy in the Kapau Village in Agam District, the cooking community, the traditional stakeholders of the Kapau Village in Agam Regency as well as the local government.

Participants will be divided into two categories, namely as respondents and informants. Respondents were determined using random sampling, which in turn would fill out distributed questionnaires. While the informants were chosen through purposive sampling to be interviewed. The informant used in this study is someone who has the capacity to answer questions about the gastronomy of Kapau Village in Agam District, for example cooks, traditional stakeholders and the local government. 
The place chosen in this study is Kapau Village, Agam Regency, West Sumatra. This place was chosen as the location of the study given the researchers' consideration of the Kapau Village which has a variety of unique foods but does not yet have a gastronomic icon.

In this study, several data collection techniques were used with the aim of obtaining information and data in accordance with research needs.

a. Observation

Observation is interpreted (Cresswell, 2013) as an activity carried out by researchers by observing, recording the behavior or activities of individuals or groups in a structured or semistructured manner. In this study, researchers will observe the leading gastronomy typical of Kapau Village in Agam Regency based on gastronomic components.

b. Distribution of Questionnaires

The questionnaire is a list of questions that are not exhaustive for research respondents who aim to get general data. The questionnaire in this study will only be distributed to typical gastronomic consumers of Kapau Village in Agam Regency, especially tourists.

c. Interview

Cresswell (2013) in his book defines interviewing as a process of collecting data by asking questions in general and unstructured with the aim of raising opinions or opinions of research. Creswell also wrote about the types of interviews including in-depth interviews, by telephone, focus group discussions, or internet interviews via email. In this study, in-depth interviews will be used to obtain the expected data in full.

The informant category in this interview is the people who are accustomed to cooking typical Kapau Village, Agam Regency, local government and tribal leaders who understand the special food there. These two categories were chosen to find out the right gastronomic icon for the area. d. Literature Study

Literature study in general that can be understood is to learn books that relate to the problem that is the main topic in the research object. According to (Meleong, 2007) it is necessary to use the views of other experts in the form of authoritative knowledge in this case which is written in the form of reference books, journals, research reports, other scientific works and also researchers can just cite the substance contained in the literature as material reference. Researchers in this case utilize this literature study by studying books that can help in the research process, both books relating to research methods or research theories. Researchers are looking for books related to conservation, traditional food, diversity, rendang, social culture, spices and herbs. In studying the books used, researchers first read first, then write down the important things needed in this study.

e. Documentation Study

Study documentation or photos is a way for researchers to collect data from the field because it can be used as a tool for qualitative research purposes. According to (Hakim, 2013) this documentation or photo study can produce descriptive data that is quite valuable and is often used to examine subjective aspects and the results are often analyzed inductively and needed in qualitative research. So the use of this photo is of enormous benefit to complement a clear data source. With all of that description in general can provide a picture of the photo as data or as a driver towards generating data and is generally not used singly to analyze data but instead, photos are used as a complement to other ways and techniques. In this case the researcher uses the study of documentation in the form of photographs to complement existing data sources in the field to provide an overview of the data or as a driver to produce data and to strengthen the data that has been collected. Researchers chose this technique with the intention that this satay can be well documented through photographs so that the results of the study 
have clear data.

\subsection{Population and Sample}

According to (Sugiyono, 2018) population is a generalization area consisting of objects / subjects that have certain qualities and characteristics determined by researchers to be studied and then drawn conclusions. So the population is not only people, but also objects and other natural objects. According to (Sugiyono, 2018) the sample is part of the number and characteristics possessed by the population . If the researcher conducts a study of a large population, while the researcher wants to examine the population and the researcher has limited funds, manpower and time, the researcher uses a sampling technique, so that generalization to the population under study.

The sample in this study will be calculated using the following formula:

$$
n=\frac{N}{N(d)^{2}+1}
$$

Note:

$\mathrm{n}=$ number of samples sought

$\mathrm{N} \quad=$ total population

$\mathrm{d}=$ precision value (determined in this amount $90 \%(\alpha=0.1)$

Then, the number of samples for the questionnaire in this study are:

$$
\begin{gathered}
n=\frac{N}{N(d)^{2}+1} \\
n=\frac{13171}{13171(0.1)^{2}+1} \\
n=\frac{13171}{131,71+1} \\
n=132
\end{gathered}
$$

Based on the above calculation, 132 respondents from 13171 populations were determined to answer the questionnaire in this study.

\subsection{Data Validity Test}

\subsubsection{Triangulation}

According to (Meleong, 2009) triangulation is a data validity checking technique that utilizes something else. Outside the data is for checking purposes or as a comparison of the two data. The most widely used technique is examination through other sources.

In research on Gastronomic Tourism Attractions in the Village of Kapau, West Sumatra, it obtained data from several sources, namely from the cooking community, traditional leaders, and the local government. Triangulation used was concurrent triangulation technique. Researchers used observation, distributing questionnaires, interviews, and documentation.

While concurrent triangulation according to (Creswell, 2010) is the researcher will collect quantitative and qualitative data at the same time at the research stage then compare between quantitative data and qualitative data to find out the combination.

Based on concurrent triangulation, in research on Gastronomic Tourism Attractions in Kapau Village, the process of inventorying leading gastronomic researchers will disseminate questionnaires to respondents and collect data on gastronomic preservation efforts by the government and the community as well as to find out what components are in the superior gastronomy of the selected Agam Regency through the interview method with several informants.

\subsubsection{Member Check}

According to (Meleong, 2007) checking with members or member check in the process of collecting important data is done in checking the degree of trust. Then check includes data, categories of analysis, interpretation, and conclusions with the members involved representing their peers who are used to react in terms of their own views and situations to the data that have 
been organized by researchers. Checking members can be done both formally and informally. This member check, if the data found agreed by the data source means the data is valid, but if the data found is not agreed by the data source then the researcher needs to discuss the data source again.

\subsection{Data analysis technique}

Data analysis is the process of simplifying data and presenting data by grouping them in a form that is easy to read and interpret (Huberman, 1992) In accordance with the research method used, namely the qualitative method.

In this research descriptive qualitative data analysis techniques will be used. In the process, data analysis is divided into three main parts, namely data reduction, data presentation and conclusion that still refers to the purpose of this study.

\subsubsection{Data reduction}

The data collected is initially raw data that must be sorted. The process of sorting and simplifying the data is known as data reduction. The researcher will make notes and summaries of data both interview data and other primary data to achieve the desired results and in accordance with the focus of the research, namely leading gastronomy in Agam Regency.

\subsubsection{Data Presentation}

The next step after reducing data is data presentation. Presentation of data is an activity when a set of information is arranged so as to give the possibility of drawing conclusions. This form of qualitative data presentation is in the form of narrative text (in the form of field notes), matrices, graphs, networks or charts. The data presented will be in the form of a descriptive description of the efforts to preserve gastronomic and leading gastronomic components in Kapau Village, Agam Regency.

\subsubsection{Withdrawal of Conclusions}

After presenting the data, the researcher will conclude the results of the data collection. Researchers will do the description of the purpose of the data obtained to reach the correct conclusions.

\section{Results and Discussion}

Kapau Village or Nagari Kapau is a village located in Tilatang Kamang Subdistrict, Agam Regency, West Sumatra which is famous for the expertise of its citizens in terms of cooking delicious food. And is a village that still holds tight customs. It has been proven since the colonial era, Nagari Kapau became one of the suppliers of food supplies for the Indonesian soldiers who were fighting against the invaders.

Pre-study was conducted on respondents who were tourists who came to Kapau Village to support the research data . The results of this pre-study shows that male and female tourists who come to Kapau Village have a nearly balanced ratio. In addition, the age range of tourists who come is very diverse, ranging from children to the elderly. Similar to age, the origin of these tourists also varies. However, most of these tourists have the same purpose of visiting, namely to carry out gastronomic tourism. The main pre-research survey results are that the type of traditional food most sought after by tourists is kapau rice.

$\mathrm{Kau} \mathrm{Kau}$ rice is one of the special foods of Kapau Village which is always present in the middle of Kapau people's lives. Kapau rice is a food dish in the form of rice and side dishes that are served together in one plate. Side dishes commonly served in Kapau Rice are Rendang, Jackfruit curry, Tulai curry, Tambusu curry, Fish curry, Jerky and Green Sambal. Although various, side dishes are not all served, usually depending on the choice of consumers.

The uniqueness of Kapau Nation can be seen based on 9 existing gastronomic components. Not only is kapau rice as a whole, each side dish in kapau rice also has its own uniqueness that makes kapau rice becoming more distinctive. First, the raw 
materials used are always natural materials. These materials are usually obtained from local traditional markets. Raw materials always depend on the cooking itself, for example meat used for rendang and meat used for different beef jerky, beef jerky must use meat that does not contain fat. For seasoning, almost all dishes use the same seasonings as Chili, Ginger, Turmeric, Galangal, and others. The main requirement for Kapau's special seasonings is not to use sugar, a large portion of salt, chili and thick coconut milk.

The process of cooking every dish is different, the main point in cooking that they always practice is the traditional cooking process which is cooking on a stove with wood or coconut fiber as the fuel. This is done to maintain the taste of cuisine.

In serving it, the K Rice and its side dishes are stored together in one plate. The ethics are that all food in a dish must be eaten until it runs out. This kapau rice is usually served as daily food or as a feast on local events such as the appointment ceremony of nagari, welcoming guests, weddings and so forth. The number of spices used and the use of natural ingredients and cooking methods that are still traditional makes the typical food of Kapau Village has good nutritional content for the body. The cooks there get recipes from ancestors that are still preserved until now, which is why your kapa rice still has a strong taste. Kapau rice has always been the main dish at various traditional events such as the appointment of a traditional leader, weddings, welcoming large guests and other parties.

The unchanging distinctive taste of Kapau special food especially in Kapau Rice makes this food even more popular even among people outside the Kapau area itself. The desire and demand of the people for rice is increasing every day. In fact, Kapau Village is now visited by many visitors from outside the area who deliberately come to taste the kapau rice dish made by native residents.
With a fairly low seller price benchmark, the purchasing power of the visitor community can be said to be high. Therefore, the cooks now dare to produce more food than there is demand. However, Kapau residents who open a typical culinary business in the village of Kapau are still few, until now there are only seven people recorded. Other cooks prefer to sell Kapau Rice in crowded tourist places such as Bukittinggi and Los Lambuang to get more buyers.

Kapau rice sellers usually charge below 50,000 rupiah for a portion of kapau rice. The price determined is according to the quality of food by tourists. In addition, kapau rice sellers usually sell from morning to night. This allows tourists to go on a gastronomic tour without having to wait for a specific time.

Based on the results of the study, it was explained that the efforts being carried out both by the local government and the community in Kapau Village, for the preservation of traditional cuisine typical of the Kapau Village had been done well. However, the efforts made are not yet optimal. One of the ongoing conservation efforts is to support Kapau Rice producers who still want to produce and sell these special dishes both inside and outside the Kapau Village area. Not only here, the local government is also trying to submit a patent application to the Indonesian government for Kapau Rice, so that Kapau Rice can be recognized by Indonesia with its original origin, namely from Nagari Kapau. Because in reality, at this time Kapau Rice does not really exist in the culinary world of Indonesia, and many people consider that Kapau Rice is the same as Padang Rice.

The local government of Kapau Village is also collaborating with the Padang State University, to make a culinary tourism project that will be located in Kapau Village, because the Kapau Village road is a crossing road for tourism objects in the Regency of Agam. The support given by the government to producers will also make 
producers more eager to produce food. In addition, efforts to patent food will also make food known to the wider public. This is an opportunity for Kapau Village to become a culinary tourism center.

The efforts made to preserve this cuisine are still not optimal, but the local government and the community in Kapau Village have and will continue to try even better to achieve the goals that they aspire to, in preserving and preserving the tradition and culture of Kapau Rice cuisine, in several ways previously explained. This method is considered capable of making Kapau Rice dishes known by more people in Indonesia, with the hope that they will be known to foreign countries as well.

The enthusiasm of the younger generation to be able to cook and the enthusiasm of the older generation to teach the younger generation to cook typical Kapau Village food are quite high. Because, the people of Kapau Village really love cooking traditional food. This is aimed at the loyalty of the cook, as well as other people who have survived to this day to continue cooking traditional Kapau Village, it has also become a tradition in Kapau Village that every child in one family must be good at cooking typical Kapau Village food and become a young generation successor to the cook there. Whatever profession they will live in the future, and even though they have to migrate outside the region, they still have to love and be able to cook traditional food typical of Kapau Village. This has become one of the factors to preserve these foods, so that the potential of Kapau Village to become a culinary tourism center is very large and can live long.

The method used to pass the cooking method to the next generation in the Kapau Village is quite easy, they are trained and deployed directly into the kitchen to help parents and grandmothers cook, so they are accustomed to cooking since childhood. Even because the traditions and culture are very strong, it makes babies even accustomed to smell the aroma of the special cuisine, which makes them able to love this gastronomy. Continuous knowledge and training done directly to the younger generation regarding cooking typical food of Kapau Village can maintain the authenticity of the food, so that even though it has changed times, the food of Kapau Village remains in its uniqueness. This can make tourists consistently visit Kapau Village for culinary tours.

There are not many promotions done by the local government, but the government has tried to keep introducing Kapau Rice to the people outside the region. There are many ways to do it, such as making Baligo Nasi Kapau advertisements on tourist crossings, and participating in festival events in collaboration with neighboring countries, as was done in 2013 at the WSF Jambore Feast Singapore. The involvement of Kapau Village special food in various traditional events can also be an added value that can increase the curiosity of tourists because in addition to culinary tours tourists can also witness local cultural tourism. Cooperation efforts with foreign countries are also very good to attract foreign tourists to come and try food in Kapau Village.

The way that is done to maintain the authenticity of the taste of Kapau Rice dishes, not only limited to preserving his cuisine. But the cook still maintains the use of traditional kitchen utensils, traditional cooking methods, the use of natural raw materials and absolutely no use of instant raw materials, which were passed down by the ancestors to keep the taste and authenticity of Kapau Rice dishes. The efforts of the food-producing community in maintaining recipes, processes and raw materials to keep up with what their ancestors taught is a value that reinforces the good impression of food to tourists. This has an impact on tourists' interest and trust towards tourists who at least survive.

Kapau Rice Cookery can not be replaced at all, changed, or added other raw 
materials, because Kapau Rice cuisine has special characteristics that are not found in other dishes. Like the use of garlic very much, the cooking process is quite long and complicated, and other characteristics. Thus, people do not dare if they have to change all the related processes that exist in Kapau Rice dishes, because if something is changed then Kapau Rice will not become Kapau Rice anymore. Fear of producers in changing recipes, processes and raw materials in food will automatically maintain a taste that is well known to tourists. Renewal to further develop food in order to become one of the leading culinary tourism destinations can be done in promotion.

The support given by the government and the community to the cooks by involving them in many celebrations will keep the cooks enthusiastic about cooking, so that efforts to make Kapau Village a culinary tourism village will be realized.

Based on the results of the study it can be concluded that the pattern of tourist trips in the Kapau Village does need special attention, because there are still many things that support to get to life in the Kapau Village is still not optimal. The factor that has not yet formed a real travel pattern makes the Kapau rice restaurant business people there still not too serious about responding to tourists and still considers that the business they are running is just an ordinary restaurant. But at this time, the local government is trying to turn Kapau Village into a gastronomic tourist attraction in West Sumatra, in collaboration with Padang State University. With the strategic location owned by Kapau Village, which can be traversed to the crossing towards major tourism objects in Agam Regency, it is a great opportunity for Kapau Village.

The businessman of Kapau Rice Restaurant there still cannot arrange the right time for visitors who want to have a gastronomic tour there, they only provide time in accordance with the opening hours of the restaurant, and because there are no tour packages provided there, they are inviting tourists resting according to his wishes. The provision of a complete and attractive tour package will make the tourist itinerary more organized so that tourists can enjoy their tour. The government also has set a time for tourist attractions in the village of Kapau with a range of 5-6 hours to follow a series of travel patterns there.

The product offered by Kapau Village is Kapau Rice. Because kapau rice is a traditional food in Kapau which has become a superior gastronomy and they make it a culinary attraction. With a wide selection of dishes to be served. The food production process carried out there is quite long, because each processing requires a long time. Can be up to 1 day or even more for cooking only. Plus all cooking tools and methods they use are still traditional. Every day, the preparation of production is assisted by husband, children and employees of business actors, because the production process is quite complicated and the number of products processed is quite large. One dish can take 2 to 3 hours. Cooking processes that take time and complicated processes become obstacles in food production. Therefore, the addition of experts by involving young people who are already trained can help simplify the process of producing food, so that food can be obtained anytime by visiting tourists. The number of requests and production is still not balanced and cannot be estimated so that they produce their food always more than the portion sold. This is a good service strategy for tourists. With the amount of production that is higher than consumer demand can be an effort to prevent the disappointment of tourists due to out of stock of the desired food.

The distance between the production kitchen and the place of business for selling in Kapau Village is not far apart, but if the businessman who sells outside Kapau Village will travel a considerable distance. For example, in Los Lambuang Bukit Tinggi, Los Lambuang is a culinary 
attraction specifically for Kapau Rice. All business people who sell in Los Lambuang are native Kapau, because basically it has become a tradition that those who are allowed to sell Kapau Rice are only Kapau bloodlines. Even though the place of selling is far outside the area, but the production kitchen is still in Kapau Village. The distance between Kapau Rice sellers in Kapau Village is still irregular, some are close together and some are far apart, only one or two sellers are far away. There are no official rules for the distance of food production sites and places to sell, and still see the current conditions. But if the gastronomic tourism development has begun, maybe the government will process the regulation. Arrangements that do not make the restaurant centralized are considered good enough so that tourists can explore the Kapau Village extensively and can explore other tourism potentials contained in the Kapau Village.

The facilities provided for tourists in the Kapau Village are still incomplete and inadequate. Only public facilities are provided there, such as prayer rooms, public toilets, and places to eat and drink only. Supposedly, culinary attractions must have adequate facilities for tourists. The main facilities such as lodging places, places of worship, public toilets, restaurants, waiting rooms, minimarkets, etc., as well as supporting facilities such as souvenir shops or souvenir shops for tourists who want to buy souvenirs, are very important factors to support the completeness from tourist attractions. The incomplete facilities are caused by the design of culinary tourist attractions in Kapau Village which have not yet been completed, so the design must be properly considered and made as much as possible, so that consumers feel comfortable and do not arise negative reviews or comments from tourists.

Kapau Village has access roads from outside the area to get to the good Kapau Village, so that transportation of two-wheeled vehicles, four-wheeled vehicles, rickshaws, and bicycles can safely pass the road in Kapau Village. Extensive parking access is also provided by the government so that it will be easier for tourists to go to Kapau Village and to store their vehicles without the need for difficulties. The strategic location is also the advantage of Kapau Village, because Kapau Village is the main crossing of two large tourism objects in the Regency of Agam. Thus, the Kapau Village has the opportunity to become a culinary tourist attraction because it is in the middle of these two big attractions. Tourists can easily come to Kapau Village to have a culinary tour and taste its culinary delights. The beautiful views of Bukit Barisan and Mount Merapi make the rural atmosphere in Kapau Village very beautiful and can make tourists more interested in coming to Kapau Village. But there are still various accesses that have not been noticed by the government, such as access to complete information to make it easier for tourists to get information about living there, which is still a special design that will be implemented by the local government in 2020.

The main activities undertaken by tourists in culinary attractions are definitely eating, but in the village of Kapau the new tourists can only do food and drink activities, without other activities provided by businesses or by the government. That is because the travel pattern pattern is still not yet capable and will only be built by the local government. Seeing other activities carried out by tourists in other culinary tourism areas, it should be a reference for the government and business actors to create culinary tourism places that are supported by offering better tourism activities and supported by providing supporting facilities, for example making special cooking training tours. and make great places for tourists to take photos.

Kapau village, which is already famous for its delicious specialties that can make the focus of tourists only focused on culinary tourism. However, the aspirations 
of tourists who say they want to learn cooking and want to do shopping in the Kapau Village must also be considered. Providing new experiences and knowledge to the tourists who come will make tourists feel the trip or visit is not in vain. Not only that, tourists can also take part in a series of several traditional events in Kapau Village so that tourists can at the same time learn the culture there.

Kapau rice becomes a superior product because Kapau Rice is indeed a superior gastronomy that is famous for its distinctive and special taste. Kapau Rice has also been known to go beyond the geographical boundaries of West Sumatra although not everyone knows about the true Kapau Rice. But there are many uniqueness - the uniqueness of the authenticity of the real Kapau Rice and can attract tourists to come and learn more about Kapau Rice.

Kapau rice which is now the identity of the Kapau people and also is a cultural heritage that is still held firmly makes the local community always make efforts aimed at preserving the existence of kapau rice. The simplest effort is to teach the next generation to be able to cook a variety of Kapau dishes. In addition, the government is currently working hard to patent kapau rice as the cultural heritage of Kapau Village.

\section{Conclusions}

Based on the results of research obtained by the author and has been presented in the previous chapter on Gastronomic Tourism Attractions in the Kapau Village, Agam Regency, West Sumatra, it can be concluded that the leading gastronomy in the Kapau Village is Napa Kapau. Kapau rice was chosen to be the leading gastronomy because this menu is most widely known and sought after by tourists. In addition, Kapau Rice is also a unique menu because it includes many other foods. Kapau Rice is a typical food of Kapau Village which contains rice, side dishes, vegetables and Sambal served in one plate. The taste and aroma of rice is very different from rice in general because it is cooked on a stove with cinnamon embers. The side dishes are also varied, the most popular ones are Jackfruit Vegetable, Rendang Kapau, Batokok Jerky and Gulai. All of these dishes are cooked using traditional herbs and are processed according to recipes and cooking procedures passed down from generation to generation. That makes the Kapau Rice special with its strength. This superior gastronomy in Kapau Village has a unique taste that has not changed from time to time. Traditional recipes and methods handed down by ancestors are still maintained today, which makes this food even more popular even among people outside the Kapau area.

The desire and demand of the people for Kapau Rice is increasingly increasing. In fact, Kapau Village is now visited by many visitors from outside the area who deliberately come to taste the Kapau Rice dish made by native residents. By benchmarking the seller's price which is quite low and in accordance with the products offered, the purchasing power of the visitor community can be said to be high. Therefore, the cooks are now brave enough to introduce Kapau Rice as a superior gastronomy that can be used as a tourist attraction and can be sold. However, Kapau residents who open a typical culinary business in the village of Kapau are still few, until now there have been only seven recorded businesses. Other cooks prefer to sell Kapau Rice in crowded tourist places such as Bukittinggi and Los Lambuang to get more buyers.

So far, the cooks, traditional stakeholders and the government have made contributions to preserve Kapau Rice. Among them, the cooks always teach and train cooking to their offspring. The adat leader always presents Kapau Village special foods in traditional ceremonies, events and parties. While the government is currently trying to patent the Kapau Rice as a special food Kapau Village is also planning to make Kapau Village one of 
West Sumatra's culinary tourism destinations and serve as a gastronomic tourist attraction because Kapau Village also has a special path that is crossed by several places famous tour in West Sumatra. Because of this favorable geographical condition, Kapau Rice sellers in Kapau Village provide a long time span for tourists who want to visit. These sellers open their shops from morning to night, this makes the tourists who come for culinary tours will not feel pressed for time. In addition, these sellers are very open to tourists who want to learn to cook, this is used as one of the additional activities that tourists can do besides visiting gastronomic tours. In addition, the completeness of facilities for the main activities of tourists who are already well available can add a positive impression to the tourists who come.

Based on the research results obtained by the author and has been presented in the previous chapter on Gastronomic Tourism Attractions in the Kapau Village, Agam Regency, West Sumatra, it can be concluded that the leading gastronomy in the Kapau Village is the Rice Kapau. Kapau rice was chosen to be the leading gastronomy because this menu is most widely known and sought after by tourists. In addition, Kapau Rice is also a unique menu because it includes many other foods.

The desire and demand of the people for Kapau Rice is increasingly increasing. In fact, Kapau Village is now visited by many visitors from outside the area who deliberately come to taste the Kapau Rice dish made by native residents. By benchmarking the seller's price which is quite low and in accordance with the products offered, the purchasing power of the visitor community can be said to be high. Therefore, the cooks are now brave enough to introduce Kapau Rice as a superior gastronomy that can be used as a tourist attraction and can be sold.

So far, the cooks, traditional stakeholders and the government have made contributions to preserve Kapau Rice. Among them, the cooks always teach and train cooking to their offspring. The adat leader always presents Kapau Village special foods in traditional ceremonies, events and parties. While the government is currently trying to patent the Kapau Rice as a special food Kapau Village is also planning to make Kapau Village one of West Sumatra's culinary tourism destinations and serve as a gastronomic tourist attraction because Kapau Village also has a special path that is crossed by several places famous tour in West Sumatra

\section{References}

Agustino, Yudi Prama. 2019. Culinary Kapau Rice from West Sumatra Become a Tourist Attraction. www.rri.co.id (Accessed 20 April 2019)

Cresswell, JW. 2013. Research Design: Qualitative, Quantitative, and Danish Approaches

Mixed. 3rd Edition of Yogyakarta.

Edward, Inskeep. 1991. Tourism Planning An Integrated and Sustainable Development Approach. New York.

Gurdjito, Murdijati. 2010. The King's Favorite Menu : Jokjakarta Culinary Wealth Portrait. Kansius. 2010

Judge, Lukman Nul. 2013. Qualitative Methodology Review : Interview with Elite Review of Qualitative Method: Interview of the Elite : 165-72.

Imelda, Josephine. 2015. National Gastronomic Dialogue Report. Gastronomic Archipelago .

Kemenpar. 2009. RI Law. www.kemenpar.go.id . (Accessed January 15, 2019) .

Kemenpar 2017. Manuscript of Culinary Potential . Final Report of Potential Culinary Manuscript Work.

Meleong. 2007. Qualitative Research Methods.

Matthew, Milles., Huberman, Michael. 1992. Qualitative Data Analysis.

Mill, RC 1990. Tourism: The International 
Business .

Nurwitasari, Ayu. 2015. The Effect of Sundanese Traditional Food

Gastronomic Tourism on the Tourist Decision to Visit the City of Bandung . Bandung Tourism College.

Nuriata 2017. Product Arrangement and Price Calculation Tour Packages . 2nd ed. Bandung: Alfabeta Bandung.

Priatna, Yolan. 2017. Information Literacy as a Key to Successful Preservation of Local Culture. 1 (2): 37-43.

Smith, Valene. 1989. The Anthropology of Tourism. University of Pensylvania

Suwantoro, Gamal. 2004. Basics of Tourism . Yogjakarta.

Sugiyono 2011. Quantitative, Qualitative, and R\&D Research Methods .

Sugiyono, 2018. Quantitative Research Methods .
Suwatno ., Turgarini, Dewi., Ningsih, Caria. 2014. West Java Flagship Gastronomic Inventory as a Tourism Base .

Turgarini, Dewi., Palupi, Santi., Fitri. 2017. Potential Culinary Tourism Scripts .

Turgarini, Dewi. 2013. Inventory Preserve Utilize and Develop West Java Flagship Gastronomy .

Turgarini, Dewi. 2018. Sundanese gastronomy as a tourist attraction in Bandung. Gadjah Mada University.

UNWTO. 2017. Triangle Concept of Gastronomy. www.kemlu.go.id . (Accessed January 15, 2019)

Winarno, Bondan. 2017. Lamaknyo! Tambusu Gulai from Nagari Kapau. www.food.detik.com (accessed April 20, 2019)

Xiaomin, Cheng. 2017. Criteria and Characteristics of City Gastronomy. 